\title{
AFLP marker linked to water-stress-tolerant bulks in barley (Hordeum vulgare L.)
}

\author{
A. Altinkut ${ }^{1}$, K. Kazan ${ }^{2}$ and N. Gozukirmizi ${ }^{1,3}$ \\ ${ }^{1}$ TUBITAK, Research Institute for Genetic Engineering and Biotechnology, Gebze-Kocaeli, Turkey. \\ ${ }^{2}$ CSIRO Plant Industry \& Cooperative Research Centre for Tropical Plant Protection, \\ The University of Queensland, John Hines Building, Brisbane, Australia. \\ ${ }^{3}$ Istanbul University, Faculty of Science, Department of Biology, Vezneciler-Istanbul, Turkey.
}

\begin{abstract}
The amplified fragment length polymorphism (AFLP) assay is an efficient method for the identification of molecular markers, useful in the improvement of numerous crop species. Bulked Segregant Analysis (BSA) was used to identify AFLP markers associated with water-stress tolerance in barley, as this would permit rapid selection of water-stress tolerant genotypes in breeding programs. AFLP markers linked to water-stress tolerance was identified in two DNA pools (tolerant and sensitive), which were established using selected $F_{2}$ individuals resulting from a cross between water-stress-tolerant and sensitive barley parental genotypes, based on their paraquat (PQ) tolerance, leaf size, and relative water content (RWC). All these three traits were previously shown to be associated with water-stress tolerance in segregating $F_{2}$ progeny of the barley cross used in a previous study. AFLP analysis was then performed on these DNA pools, using 40 primer pairs to detect AFLP fragments that are present/absent, respectively, in the two pools and their parental lines. One separate AFLP fragment, which was present in the tolerant parent and in the tolerant bulk, but absent in the sensitive parent and in the sensitive bulk, was identified. Polymorphism of the AFLP marker was tested among tolerant and sensitive $F_{2}$ individuals. The presence of this marker that is associated with water-stress tolerance will greatly enhance selection for paraquat and water-stress tolerant genotypes in future breeding programs.
\end{abstract}

Key words: bulked segregant analysis, drought, Hordeum vulgare, AFLP, paraquat.

Received: April 22, 2002; accepted: November 8, 2002.

\section{Introduction}

Water stress is one of the greatest yield-reducing factors. It causes various physiological and biochemical effects on plants (Tanaka et al., 1990; Irigoyen et al., 1992; Smirnoff, 1993; Bohnert and Jensen, 1996; Jamaux, 1997; Tabaeizadeh, 1998), and is therefore a serious problem in many parts of the world where barley, wheat, and other small-grained cereals form the staple diets (Quarrie et al., 1999). This is true not only in arid and semiarid regions, but also in places where total precipitation is high, but is not evenly distributed over the growing season (Ribaut et al., 1997). The effects of water stress upon leaf physiology could be mediated by the production and accumulation of toxic reactive oxygen intermediates. Reactive oxygen intermediates generated during water stress may represent a serious challenge to a number of cellular functions. For in-

Send correspondence to Dr. Ahu Altinkut, TUBITAK, Research Institute for Genetic Engineering and Biotechnology, P.O Box 21, 41470, Gebze-Kocaeli, Turkey. E-mail: ahualtinkut@ hotmail.com. stance, chlorophyll destruction, serious de-organization of chloroplast fine structure, and enzyme inactivation can be due to these toxic oxygen forms (Irigoyen et al., 1992). These effects of water stress on the physiology of the plants is very similar to the stress caused by the peroxidizing herbicide paraquat $(\mathrm{PQ})$, which leads to the production of highly toxic free radicals generated by reaction of molecular oxygen with PQ radicals formed in the chloroplast during photosynthesis (Dodge, 1971). Therefore, a close correlation is expected between the plant's tolerance to stresses imposed by water and PQ. It is also possible that drought-tolerant plants can be selected based on their response to PQ in segregating breeding populations (Altinkut et.al., 2001). Other morphological and physiological traits of interest with respect to water-stress tolerance mechanisms include leaf size and relative water content (RWC) (Teulat et al., 1997 a, b; Grainer and Tardieu, 1999; Gonzalez et al., 1999). In our previous study (Altinkut et al., 2001), we reported that leaf size, RWC and PQ tolerance 
are associated with enhanced tolerance to water-stress in barley and wheat.

Tolerance to water-stress must be incorporated into breeding material to be grown in regions of low rainfall. However, a major constraint in introducing this trait into otherwise elite genotypes is the lack of meaningful selection criteria. An alternative would be to identify molecular markers associated with water-stress tolerance, and to use these markers to indirectly select for tolerance (Courtois et al., 2000). Molecular marker analysis allows to identify genome segments contributing to the genetic variance of a trait, and thus to select superior genotypes at these loci, without uncertainties regarding the genotype, due to environment interaction and experimental error.

The amplified Fragment Length Polymorphism (AFLP) technique (Vos et al., 1995) is based on the amplification of selected restriction fragments of a total genomic digest by PCR, and separation of labeled amplified products by denaturing polyacrylamide gel electrophoresis (Becker et al., 1995). It has been extensively used for developing polymorphic markers linked to important agronomic traits. High reproducibility, rapid generation, and high frequency of identifiable polymorphisms make AFLP analysis an attractive technique for determining linkages by analyzing individuals from segregating populations (Goodwin et al., 1998; Hartl et al., 1999). In this study, we have used the bulked segregant analysis (BSA) technique (Michelmore et al., 1991) in combination with AFLPs to identify potential molecular marker(s) associated with water-stress tolerance in barley, so that these markers shall be used for selecting water-stress tolerance in segregating populations.

\section{Material and Methods}

\section{Plant material}

Eighty $\mathrm{F}_{2}$ plants from the cross Tokak x ST 5819 and their parental lines were grown in individual pots with a soil mixture containing soil/sand/organic matter at a ratio of $1: 1: 1$. All plants were grown in a growth chamber at $23^{\circ} \mathrm{C}$, $70 \%$ humidity, and $16 \mathrm{~h}$ light $/ 8 \mathrm{~h}$ dark periods.

\section{Screening the $F_{2}$ mapping population for water-stress tolerance}

The methods used for selecting water-stress tolerance in barley plants were described previously (Altinkut et al., 2001). Briefly, to prepare bulks, leaf chlorophyll content after PQ treatment, leaf size, and RWC from the tolerant and sensitive parents of the barley cross and its $\mathrm{F}_{2}$ population of 80 individuals were measured. Leaf size and chlorophyll content after PQ treatment were measured on the $2^{\text {nd }}$ top leaf, taken from the plants during the pre-flowering stage. Leaf extracts were analyzed for determination of chlorophyll content, after treating leaves with $100 \mu \mathrm{M} P Q$ solution, under a light intensity of 12000 lux for $24 \mathrm{~h}$. RWC were measured on the $6^{\text {th }}$ day of water stress.

\section{Bulked segregant analysis with AFLPs}

Freeze-dried leaf materials from $\mathrm{F}_{2}$ individuals and parents were extracted for genomic DNA, according to the method described by Lodhi et al. (1994). Bulked segregant analysis with AFLP markers was used to identify markers associated with water-stress tolerance in the population Tokak x ST5819. Aliquots of DNA from seven tolerant and seven sensitive plants were combined to produce bulks.

Four AFLP reactions were performed with each primer pair on the DNA extracted from the following groups of barley plants: (1) the tolerant parent; (2) the sensitive parent; (3) the pooled DNA of the most tolerant $F_{2}$ plants; and (4) the pooled DNA of the most sensitive $F_{2}$ plants. The AFLP procedure was performed as described by Zabeau and Vos (1993) and Vos et al. (1995), and comprised of three steps, as follows.

Template DNA preparation: $0.5 \mu \mathrm{g}$ DNAs from bulks and parents were restricted with $5 \mathrm{U}$ MseI (Gibco BRL, MD, USA) (a frequent 4-base cutter) and 5 U Pst (Gibco $\mathrm{BRL}$ ) (a rare 6-base cutter) in a restriction-ligation buffer (250 mM Tris-HCI (pH 7.6), $50 \mathrm{mM} \mathrm{MgCl}_{2}, 5 \mathrm{mM}$ ATP, $5 \mathrm{mM} \mathrm{DTT}, 25 \% \mathrm{w} / \mathrm{v}$ polyethylene glycol-8000) for $16 \mathrm{~h}$ at $37^{\circ} \mathrm{C}$, in a total volume of $50 \mu \mathrm{L}$. After checking for complete digestion, the digested DNAs were ligated to MseI adaptor (5'-GACGATGAGTCCTGAG-'3; 3'-TACTCA GGACTCAT-'5) (50 pmol) and PstI adaptor (5'-CTCGTA GACTGCGTACATGCA-'3; 3'-CATCTGACGCATGT-'5) (5 pmol), using $1 \mathrm{U} / \mu \mathrm{L}$ T4 DNA ligase (Gibco BRL) and 1 mM ATP (Gibco BRL), for $6 \mathrm{~h}$ at $37^{\circ} \mathrm{C}$. Prepared template DNAs were stored at $4{ }^{\circ} \mathrm{C}$ until required.

Pre-amplification: After adaptor ligation, preamplification of DNA fragments was performed using Vos et al.'s (1995) primer notation moo/poo non-selective primer combinations in a $25 \mu \mathrm{L}$ reaction containing the following: $2 \mu \mathrm{L}$ of ligated DNA, $50 \mathrm{ng}$ moo primer (5'-GAC GATGAGTCCTGAGTAA-' 3 ) and $50 \mathrm{ng}$ poo primer (5'CTCGTAGACTGCGTACATGCA-'3), 0.2 mM dNTP's, 1X PCR buffer and $0.5 \mathrm{U}$ Taq polymerase (Promega, WI, USA). Samples were run in a PTC-100 MJ thermocycler (MJ Research, Watertown, MA) for 20 cycles of $94{ }^{\circ} \mathrm{C}$ (30 s), $56^{\circ} \mathrm{C}(1 \mathrm{~min})$, and $72{ }^{\circ} \mathrm{C}(1 \mathrm{~min})$. Pre-amplification products were then diluted $5 \mathrm{X}$ in double-distilled $\mathrm{H}_{2} \mathrm{O}$, and used as templates for selective amplification.

Selective amplification: Selective amplification of the pre-amplified DNA was carried out using various selective primer combinations of moo $(\mathrm{moo}+\mathrm{CAC}$, moo $+\mathrm{ACC}$, moo+CCA, moo+CAA, moo+ACG, moo $+\mathrm{CAG}$, moo+CAT moo+CGA, moo+CGT, moo+CCT) and poo (poo+CCA, poo+GTT, poo+GAC, poo $+\mathrm{TGG})$, with 3-base-pair extension in a $25 \mu \mathrm{L}$ reaction containing: $5 \mu \mathrm{L}$ diluted pre-amplification product, $50 \mathrm{ng}$ selective moo primer and $50 \mathrm{ng}$ selective poo primer, $0.2 \mathrm{mM}$ dNTPs, $1 \mathrm{X}$ PCR buffer, and $0.5 \mathrm{U}$ Taq polymerase (Promega). The following cycle profile ensured optimal selective amplifica- 
tion: one cycle of $1 \mathrm{~min}$ at $94{ }^{\circ} \mathrm{C}, 1 \mathrm{~min}$ at $65^{\circ} \mathrm{C}$, and $1 \mathrm{~min}$ $30 \mathrm{~s}$ at $72^{\circ} \mathrm{C}$, followed by 11 cycles of $1{ }^{\circ} \mathrm{C}$ lower annealing temperature each cycle, and 22 cycles of $30 \mathrm{~s}$ at $94{ }^{\circ} \mathrm{C}, 30 \mathrm{~s}$ at $56^{\circ} \mathrm{C}$, and $1 \mathrm{~min}$ at $72{ }^{\circ} \mathrm{C}$.

\section{Electrophoresis}

Amplification products were separated on a $6 \%$ polyacrylamide (acrylamide: bisacrylamide $=19: 1) / 8 \mathrm{M}$ urea sequencing gel at $1750 \mathrm{~V}$ for $3 \mathrm{~h}$ in $1 \mathrm{X}$ TBE buffer (0.09 M Tris-borate and $0.002 \mathrm{M}$ EDTA), and detected by silver staining according to the manufacturer's instructions (Promega). Band sizes were determined by comparison with a 10 base-pair (bp) DNA ladder size standard from Gibco-BRL (MD, USA).

\section{Results and Discussion}

The main objective of this study was to determine whether different polymorphic AFLP markers could be identified in barley bulks made up based on traits associated with water-stress tolerance. Since water-stress tolerance is a quantitatively inherited trait, controlled by several genetic loci, which are difficult to measure (Forster et al., 2000), identification of molecular markers associated with a major locus contributing to water-stress tolerance would be useful for indirect selection for water-stress tolerance (Altinkut and Gozukirmizi, 2003). However, in most instances, identifying genetic markers associated with important genes or traits requires screening of a relatively large number of individuals in the population (Lawson et al., 1994). For this reason we chose to use BSA, since comparing bulk samples is more convenient than evaluating many individuals in different populations (Sweeney and Danneberger, 1994).

To constitute bulks, individual barley $\mathrm{F}_{2}$ plants from cross between water-stress tolerant (Hordeum vulgare $\mathrm{L}$. cv. 'Tokak' - a known water-stress tolerant cultivar) and water-stress sensitive $(H$. vulgare L. 'ST 5819' - a highly water-stress sensitive line) barley plants were used to prepare the water-stress tolerant and sensitive bulks. Each water-stress tolerant and sensitive bulk included 7 selected $F_{2}$ plants. The methods used for selecting water-stress tolerance in these barley plants were described previously (Altinkut et al., 2001). Briefly, the parental barley genotypes used here differed in their leaf chlorophyll content following PQ treatment, leaf size, and RWC. These traits were scored in the barley cross $\mathrm{F}_{2}$ population of 80 individuals (Table 1). To prepare the bulks, leaf chlorophyll content after PQ treatment was measured from the tolerant and sensitive parent of the barley cross and its individual segregating $F_{2}$ plants. Seven $F_{2}$ plants that fell in the extreme ends of the distribution for leaf chlorophyll content were then selected to prepare the tolerant and sensitive bulks. In addition, RWC and leaf size were measured in $\mathrm{F}_{2}$ plants and their parental genotypes. As shown in Table 1, plants with higher chlorophyll content also had smaller leaves and
Table 1 - Morphological and physiological data used for making the water stress tolerant and sensitive barley and wheat bulks in both parental lines and their selected $\mathrm{F}_{2}$ individuals. Measurements of leaf size and chlorophyll content after PQ treatment were conducted on the $2^{\text {nd }}$ top leaf taken from the plants during the preflowering stage. Leaf extracts were analysed for determination of chlorophyll content after treating leaves with $100 \mu \mathrm{M}$ PQ solution under a light intensity of 12000 lux for $24 \mathrm{~h}$. Application of water stress and measurement of RWC were according to Altinkut et al. (2001). *Values presented for parental genotypes were averages of data taken from 20 parental plants.

\begin{tabular}{|c|c|c|c|c|}
\hline & A & $\mathrm{B}$ & Leaf size $\left(\mathrm{cm}^{2}\right)$ & RWC (\%) \\
\hline \multicolumn{5}{|c|}{ Barley parental lines } \\
\hline *Tokak (T) & $2.0 \pm 0.07$ & $1.25 \pm 0.12$ & $20 \pm 5.9$ & $58 \pm 1.3$ \\
\hline *ST $5819(\mathrm{~S})$ & $1.95 \pm 0.08$ & $0.125 \pm 0.04$ & $43 \pm 7.2$ & $45 \pm 2.2$ \\
\hline \multicolumn{5}{|c|}{ Tolerant $\mathrm{F}_{2}$ individuals } \\
\hline $\mathrm{F}_{2}-1$ & - & 1.43 & 11 & 60 \\
\hline $\mathrm{F}_{2}-2$ & - & 1.44 & 11 & 60 \\
\hline $\mathrm{F}_{2}-3$ & - & 1.45 & 12.8 & 61.5 \\
\hline $\mathrm{F}_{2}-5$ & - & 1.39 & 13.5 & 61.5 \\
\hline $\mathrm{F}_{2}-6$ & - & 1.426 & 14 & 63 \\
\hline $\mathrm{F}_{2}-22$ & - & 1.28 & 21.5 & 57 \\
\hline $\mathrm{F}_{2}-25$ & - & 1.3 & 22 & 59.5 \\
\hline \multicolumn{5}{|c|}{ Sensitive $F_{2}$ individuals } \\
\hline $\mathrm{F}_{2}-70$ & - & 0.163 & 43 & 42 \\
\hline $\mathrm{F}_{2}-73$ & - & 0.122 & 45.5 & 46.8 \\
\hline $\mathrm{F}_{2}-75$ & - & 0.098 & 49.5 & 35 \\
\hline $\mathrm{F}_{2}-77$ & - & 0.128 & 52.5 & 43 \\
\hline $\mathrm{F}_{2}-78$ & - & 0.066 & 54 & 33 \\
\hline $\mathrm{F}_{2}-79$ & - & 0.048 & 55.2 & 32 \\
\hline $\mathrm{F}_{2}-80$ & - & 0.036 & 59 & 28 \\
\hline
\end{tabular}

Wheat parental lines

\begin{tabular}{llccc}
\hline *Kirac (T) & $2.95 \pm 0.03$ & $2.5 \pm 0.25$ & $39 \pm 6.4$ & $72 \pm 4.4$ \\
$*$ Sultan $95(\mathrm{~S})$ & $2.65 \pm 0.09$ & $0.14 \pm 0.03$ & $65 \pm 6.2$ & $56 \pm 2.9$
\end{tabular}

Tolerant $\mathrm{F}_{2}$ individuals

\begin{tabular}{lllll}
\hline $\mathrm{F}_{2}-1$ & - & 3 & 31.2 & 80 \\
$\mathrm{~F}_{2}-2$ & - & 3 & 31.2 & 79.6 \\
$\mathrm{~F}_{2}-3$ & - & 2.9 & 32 & 80 \\
$\mathrm{~F}_{2}-4$ & - & 2.9 & 32 & 78 \\
$\mathrm{~F}_{2}-5$ & - & 2.88 & 33.6 & 77.3 \\
$\mathrm{~F}_{2}-6$ & - & 2.85 & 33 & 76 \\
$\mathrm{~F}_{2}-7$ & - & 2.8 & 34.5 & 75 \\
$\mathrm{~F}_{2}-8$ & - & 2.78 & 35 & 75 \\
\hline
\end{tabular}

Sensitive $\mathrm{F}_{2}$ individuals

\begin{tabular}{lllll}
\hline $\mathrm{F}_{2}-73$ & - & 0.9 & 69 & 45 \\
$\mathrm{~F}_{2}-74$ & - & 0.6 & 70.9 & 48 \\
$\mathrm{~F}_{2}-75$ & - & 0.5 & 70 & 46.5 \\
$\mathrm{~F}_{2}-76$ & - & 0.55 & 70 & 48 \\
$\mathrm{~F}_{2}-77$ & - & 0.6 & 71.2 & 48 \\
$\mathrm{~F}_{2}-78$ & - & 0.6 & 72.1 & 48 \\
$\mathrm{~F}_{2}-79$ & - & 0.5 & 73 & 47.8 \\
$\mathrm{~F}_{2}-80$ & - & 0.1 & 75 & 45 \\
\hline
\end{tabular}

A: Chlorophyll Content in untreated leaves $\mathrm{mg} / \mathrm{chlorophyll/fresh} \mathrm{weight.}$ B: Chlorophyll Content in PQ treated leaves mg/chlorophyll/fresh weight. 
Table 2 - Morphological and physiological data of parental lines* and their $\mathrm{F}_{2}$ individuals, used to make up the water-stress tolerant and sensitive barley bulks.

\begin{tabular}{|c|c|c|c|c|}
\hline & Leaf size $\left(\mathrm{cm}^{2}\right)$ & $\mathrm{A}$ & B & C \\
\hline Tokak* & 20 & 2 & 1.25 & 57.6 \\
\hline ST5819* & 43 & 1.95 & 0.125 & 44.9 \\
\hline $\mathrm{F}_{2}-1^{\mathrm{T}}$ & 11 & - & 1.43 & 60 \\
\hline $\mathrm{F}_{2}-2^{\mathrm{T}}$ & 11 & - & 1.44 & 60 \\
\hline $\mathrm{F}_{2}-3^{\mathrm{T}}$ & 12.8 & - & 1.45 & 61.5 \\
\hline $\mathrm{F}_{2}-4^{\mathrm{T}}$ & 13.5 & - & 1.39 & 61.5 \\
\hline $\mathrm{F}_{2}-5^{\mathrm{T}}$ & 14 & - & 1.42 & 63 \\
\hline $\mathrm{F}_{2}-6^{\mathrm{T}}$ & 21.8 & - & 1.53 & 62 \\
\hline $\mathrm{F}_{2}-7^{\mathrm{T}}$ & 22 & - & 1.3 & 59.5 \\
\hline $\mathrm{F}_{2}-8$ & 21.5 & - & 1.28 & 57 \\
\hline $\mathrm{F}_{2}-9$ & 13 & - & 0.65 & 49.5 \\
\hline $\mathrm{F}_{2} 10$ & 15 & - & 0.17 & 45.3 \\
\hline$F_{2}-11$ & 15 & - & 0.43 & 50.5 \\
\hline $\mathrm{F}_{2}-12$ & 15 & - & 0.5 & 49.5 \\
\hline $\mathrm{F}_{2}-13$ & 15.3 & - & 0.54 & 48.6 \\
\hline $\mathrm{F}_{2}-14$ & 16 & - & 0.44 & 48 \\
\hline $\mathrm{F}_{2}-15$ & 16.5 & - & 0.55 & 53 \\
\hline $\mathrm{F}_{2}-16$ & 17 & - & 0.41 & 51 \\
\hline$F_{2}-17$ & 17 & - & 0.47 & 51.3 \\
\hline $\mathrm{F}_{2}-18$ & 18 & - & 0.48 & 55 \\
\hline $\mathrm{F}_{2}-19$ & 19 & - & 0.52 & 52 \\
\hline $\mathrm{F}_{2}-20$ & 19 & - & 0.79 & 49 \\
\hline $\mathrm{F}_{2}-21$ & 19 & - & 0.47 & 52 \\
\hline $\mathrm{F}_{2}-22$ & 19.5 & - & 1.12 & 55.5 \\
\hline $\mathrm{F}_{2}-23$ & 20 & - & 0.41 & 51 \\
\hline $\mathrm{F}_{2}-24$ & 21 & - & 0.34 & 47 \\
\hline $\mathrm{F}_{2}-25$ & 22 & - & 0.31 & 49 \\
\hline $\mathrm{F}_{2}-26$ & 22.1 & - & 0.42 & 51 \\
\hline $\mathrm{F}_{2}-27$ & 23 & - & 0.38 & 41 \\
\hline $\mathrm{F}_{2}-28$ & 23 & - & 0.4 & 45.5 \\
\hline $\mathrm{F}_{2}-29$ & 23 & - & 1.02 & 53.5 \\
\hline $\mathrm{F}_{2}-30$ & 23.2 & - & 0.42 & 45 \\
\hline $\mathrm{F}_{2}-31$ & 24 & - & 1.1 & 57.5 \\
\hline $\mathrm{F}_{2}-32$ & 24 & - & 0.9 & 50.5 \\
\hline $\mathrm{F}_{2}-33$ & 24.6 & - & 1.21 & 58 \\
\hline $\mathrm{F}_{2}-34$ & 24 & - & 0.32 & 45 \\
\hline $\mathrm{F}_{2}-35$ & 25 & - & 0.92 & 53 \\
\hline $\mathrm{F}_{2}-36$ & 25.8 & - & 0.69 & 48.5 \\
\hline$F_{2}-37$ & 27 & - & 0.84 & 52.5 \\
\hline $\mathrm{F}_{2}-38$ & 27.3 & - & 0.2 & 42 \\
\hline $\mathrm{F}_{2}-39$ & 27 & - & 0.4 & 46 \\
\hline $\mathrm{F}_{2}-40$ & 27 & - & 0.94 & 51 \\
\hline $\mathrm{F}_{2}-41$ & 27 & - & 0.65 & 58 \\
\hline $\mathrm{F}_{2}-42$ & 27 & - & 0.35 & 48 \\
\hline
\end{tabular}

\begin{tabular}{|c|c|c|c|c|}
\hline & Leaf size $\left(\mathrm{cm}^{2}\right)$ & A & B & $\mathrm{C}$ \\
\hline $\mathrm{F}_{2}-43$ & 28 & - & 0.24 & 44 \\
\hline $\mathrm{F}_{2}-44$ & 28.7 & - & 1.09 & 53 \\
\hline $\mathrm{F}_{2}-45$ & 29 & - & 0.55 & 42 \\
\hline $\mathrm{F}_{2}-46$ & 29 & - & 0.28 & 43 \\
\hline $\mathrm{F}_{2}-47$ & 29.2 & - & 0.23 & 45 \\
\hline $\mathrm{F}_{2}-48$ & 29.8 & - & 0.96 & 52 \\
\hline $\mathrm{F}_{2}-49$ & 30.2 & - & 0.98 & 54 \\
\hline $\mathrm{F}_{2}-50$ & 30 & - & 0.2 & 47 \\
\hline $\mathrm{F}_{2}-51$ & 31 & - & 0.57 & 50 \\
\hline $\mathrm{F}_{2}-52$ & 31 & - & 0.46 & 42 \\
\hline $\mathrm{F}_{2}-53$ & 31.6 & - & 1.08 & 59 \\
\hline $\mathrm{F}_{2}-54$ & 31 & - & 0.26 & 45 \\
\hline $\mathrm{F}_{2}-55$ & 31.5 & - & 0.86 & 51.2 \\
\hline $\mathrm{F}_{2}-56$ & 32.3 & - & 0.91 & 52 \\
\hline $\mathrm{F}_{2}-57$ & 32 & - & 0.56 & 49 \\
\hline $\mathrm{F}_{2}-58$ & 32 & - & 0.73 & 50.8 \\
\hline $\mathrm{F}_{2}-59$ & 32.2 & - & 0.21 & 46.8 \\
\hline $\mathrm{F}_{2}-60$ & 32.2 & - & 0.27 & 45 \\
\hline $\mathrm{F}_{2}-61$ & 33 & - & 0.23 & 51 \\
\hline $\mathrm{F}_{2}-62$ & 33 & - & 0.92 & 53.9 \\
\hline $\mathrm{F}_{2}-63$ & 34 & - & 0.86 & 50 \\
\hline $\mathrm{F}_{2}-64$ & 35 & - & 0.26 & 48 \\
\hline $\mathrm{F}_{2}-65$ & 35 & - & 0.5 & 47 \\
\hline $\mathrm{F}_{2}-66$ & 35 & - & 0.62 & 56 \\
\hline $\mathrm{F}_{2}-67$ & 39 & - & 0.79 & 50 \\
\hline $\mathrm{F}_{2}-68$ & 41 & - & 0.71 & 49.4 \\
\hline $\mathrm{F}_{2}-69$ & 41 & - & 0.61 & 47 \\
\hline $\mathrm{F}_{2}-70$ & 43 & - & 0.16 & 42 \\
\hline $\mathrm{F}_{2}-71$ & 52 & - & 0.92 & 51.5 \\
\hline $\mathrm{F}_{2}-72$ & 45.7 & - & 0.27 & 45 \\
\hline $\mathrm{F}_{2}-73$ & 45 & - & 0.9 & 52 \\
\hline $\mathrm{F}_{2}-74^{\mathrm{S}}$ & 45.5 & - & 0.12 & 46.8 \\
\hline $\mathrm{F}_{2}-75^{\mathrm{S}}$ & 47.5 & - & 0.15 & 48 \\
\hline$F_{2}-76^{S}$ & 49.5 & - & 0.09 & 35 \\
\hline $\mathrm{F}_{2}-77^{\mathrm{S}}$ & 52.5 & - & 0.12 & 43 \\
\hline $\mathrm{F}_{2}-78^{\mathrm{S}}$ & 54 & - & 0.06 & 33 \\
\hline $\mathrm{F}_{2}-79^{\mathrm{S}}$ & 55.2 & - & 0.04 & 32 \\
\hline $\mathrm{F}_{2}-80^{\mathrm{S}}$ & 59 & - & 0.03 & 28 \\
\hline
\end{tabular}

*Values presented for parental genotypes are averages of data from 20 parental plants. A: Chlorophyll content in untreated leaves (mg/chlorophyll/fresh weight). B: Chlorophyll content in PQ treated leaves (mg/ chlorophyll/fresh weight). C: RWC on $6^{\text {th }}$ day of water stress.

*Values presented for parental genotypes are averages of data from 20 parental plants.

${ }^{\mathrm{T}}$ : tolerant $\mathrm{F}_{2}$ individuals selected for bulk.

$\mathrm{s}$ : sensitive $\mathrm{F}_{2}$ individuals selected to constitute the bulks. 


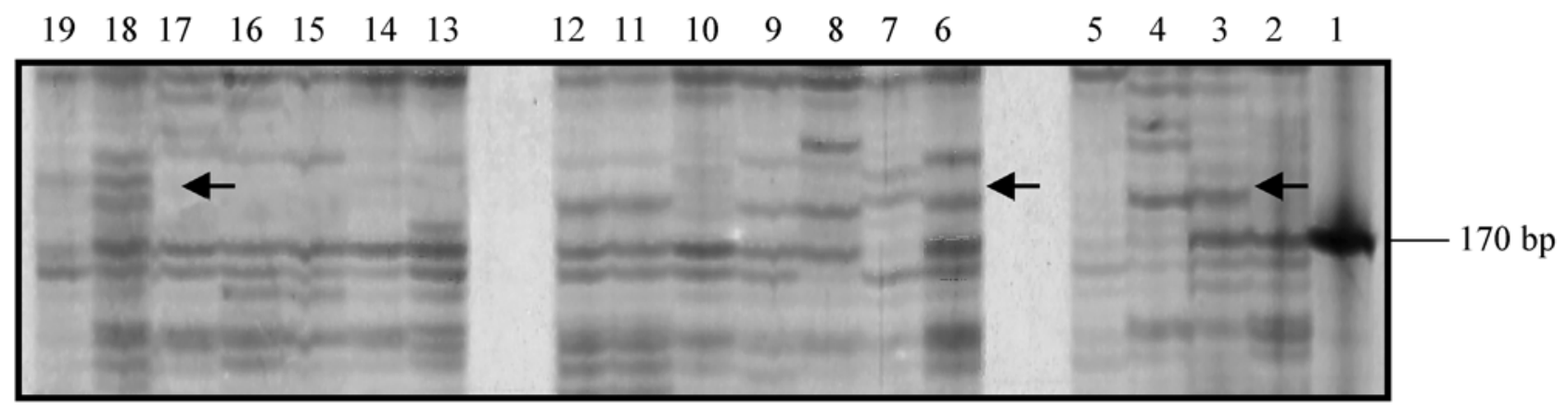

Figure 1 - Results of AFLP amplification based on the use of primers moo+CAT / poo+TGG in barley. 1-10 bp ladder, amplification from sensitive parent ST5819 (2), tolerant parent Tokak (3), tolerant bulk (4), sensitive bulk (5). 6-12: tolerant $\mathrm{F}_{2}$ individuals, 13-19: sensitive $\mathrm{F}_{2}$ individuals. AFLP marker is indicated with an arrow (only relevant part of the representative gel is shown).

higher RWC values. The correlation coefficient calculated for PQ tolerance and leaf size was significant (r: -0.423 , $\mathrm{p}>0.05)$. We then examined the correlation between PQ tolerance and RWC, and the correlation coefficient calculated was highly significant ( $\mathrm{r}: 0.830, \mathrm{p}>0.05)$. Finally, the association between RWC and leaf size also showed a significant correlation ( $r$ : $-0.593, p>0.05$ ).

AFLP fingerprinting was then used to identify markers potentially associated with water-stress tolerance. Combinations of ten MseI primers and four PstI primers, each with three selective bases, on DNA from pooled samples, were used in barley DNA. The DNA pools that we used in this study included $F_{2}$ individuals selected for their morphological and physiological traits associated with water-stress tolerance. Approximately 12000 AFLP fragments amplified from barley using a total of 40 primer combinations were analyzed by running on polyacrylamide gels. A majority of the 40 primer pair combinations produced amplification patterns, which were not different between the tolerant and sensitive bulks and their parents. However, one primer pair produced an amplification product that was present in the tolerant parent and in the tolerant bulk, but not in the sensitive one. The primer pair moo+CAT / poo+TGG amplified a DNA fragment of $172 \mathrm{bp}$, which was present in the tolerant parent and in the tolerant bulk, but not in the sensitive one. The segregation of this marker in the 14 individuals, which constituted the bulks was tested. The $172 \mathrm{bp}$ fragment was present in six out of seven individuals in the tolerant bulk, and was absent in six out of seven individuals in the sensitive bulk. Only 1 sensitive plant generated the polymorphic band (Figure 1). It was significant that the single $F_{2}$ plant in the sensitive bulk which generated the $172 \mathrm{bp}$ fragment, and the single $\mathrm{F}_{2}$ plant in the tolerant bulk which did not generate the $172 \mathrm{bp}$ fragment were two of the misclassified individuals, possibly due to selection error, and that, despite this, BSA was successfully used to identify the fragment. The reproducible amplification of this fragment in repeated amplifications suggests that it is associated with a major gene(s) that contributes to enhanced tolerance to water-stress- associated traits. The results also demonstrate that a BSA strategy may be useful even for the identification of markers for quantitative traits, such as water-stress tolerance. Recently, similar approaches have been used to identify markers associated with other quantitatively inherited traits, namely anther culture response in potato (BoluarteMedina and Veilleux, 2002), economically important traits in Pinus (Lerceteau et al., 2000), and disease resistance in tomato (Peleman, 1999). However, to determine the transportability of the marker identified in this study to other genotypes, other crosses derived from different parental genotypes should be evaluated. In this regard, the present study only focussed on the barley genotype that is most commonly used in breeding programs in Turkey as a source of drought tolerance.

The marker identified in this study, once verified in other barley genotypes, would allow implementation of marker-assisted selection. We expect that this marker may be even more useful when converted into a simplesequence PCR-based marker that can be used for largescale water-stress tolerance screening of segregating populations.

\section{Acknowledgements}

We would like to thank Dr. Nora Lapitan (Colorado State University, Department of Soil \& Crop Sciences) for allowing Dr. A. Altinkut to perform AFLP reactions in her laboratory. This study was supported in part by TUBITAK, Eureka Office, in the frame of the Eureka 1322 CerealStresstol Project, and by the Research Foundation of the University of Istanbul, Project No. 1676/15082001.

\section{References}

Altinkut A, Kazan K, Ipekci Z and Gozukirmizi N (2001) Tolerance to paraquat is correlated with the traits associated water stress tolerance in segregating $\mathrm{F}_{2}$ populations of barley and wheat. Euphytica 121:81-86.

Altinkut A and Gozukirmizi N (2003) Search for microsatellite markers associated with water stress tolerance in wheat 
through bulked segregant analysis. Molecular Biotechnology 23(2):97-106.

Becker J, Vos P, Kuiper M, Salamini F and Heun M (1995) Combined mapping of AFLP and RFLP markers in barley. Mol Gen Genet 249:65-73.

Bohnert HJ and Jensen RG (1996) Strategies for engineering water-stress tolerance in plants. Trends Biotech 14:89-97.

Boluarte-Medina T and Veilleux RE (2002) Phenotypic characterization and bulk segregant analysis of anther culture response in two backcross families of diploid potato. Plant Cell Tiss Org Cult 68:277-286.

Courtois B, Mclaren G, Sinha PK, Prasad K, Yadav R and Shen L (2000) Mapping QTLs associated with drought avoidance in upland rice. Molec Breeding 6:55-66.

Dodge AD (1971) The mode of action of the dibyridylium herbicides, paraquat and diquat. Endeavour 30:130-135.

Forster BP, Ellis RP, Thomas WT, Newton AC, Tuberosa R, This D, Bahri RA, El-enenin MH and Ben Salem M (2000) The development and application of molecular markers for abiotic stres tolerance in barley. J Exp Bot 51:19-27.

Gonzalez A, Martin I and Ayerbe I (1999) Barley yield in water-stress conditions. The influence of precocity, osmotic adjustment and stomatal conductance. Field Crops Res 62:23-34.

Goodwin SB, Hu X and Shaner G (1998) An AFLP marker linked to a gene for resistance to Septoria tritici blotch in wheat. Proc. $9^{\text {th }}$ Int. Wheat Genet. Symp. 3:108-110, A.E. Slinkard (ed), Univ. Extension Press, Univ. of Saskatchewan, Saskatoon.

Granier C and Tardieu F (1999) Water deficit and spatial pattern of leaf development. Variability in responses can be simulated using a simple model of leaf development. Plant Physiol 119:609-619.

Hartl L, Mohler V, Zeller FJ, Hsam SLK and Schweizer G (1999) Identification of AFLP markers closely linked to the powdery mildew resistance genes pm $1 \mathrm{c}$ and pm4a in common wheat (Triticum aestivum L.). Genome 42:322-329.

Irigoyen JJ, Emerich DW and Sanchez-Diaz M (1992) Alfalfa leaf senescence induced by drought stress: photosynthesis, hydrogen peroxide metabolism, lipid peroxidation and ethylene evolution. Physiol Plant 84:67-72.

Jamaux I, Steinmetz A and Belhassen E (1997) Looking for molecular and physiological markers of osmotic adjustment in sunflower. New Phytol 137:117-127.

Lawson WR, Henry RJ, Kochman JK and Kong GA (1994) Genetic diversity in sunflower (Helianthus annuus L.) as revealed by random amplified polymorphic DNA analysis. Aust J Agric Res 45:1319-1327.

Lerceteau E, Plomion C and Andersson B (2000) AFLP mapping and detection of quantitative trait loci (QTLs) for economi- cally important traits in Pinus sylvestris: a preliminary study. Molec Breeding 6:451-458.

Lodhi MA, Ye GN, Weeden NF and Reisch BI (1994) Simple and efficient method for DNA extraction from Gravepine cultivars and Vitis species. Mol Biol Rep 23:6-13.

Michelmore RW, Paran I and Kesseli RV (1991) Identification of markers linked to disease genes by bulked segregant analysis: A rapid method to detect markers in specific genomic regions by using segregating populations. Proc Natl Acad Sci USA 88:9828-9832.

Peleman J (1999) Which DNA marker for which purpose? In: Gillet, EM (ed) Application of the AFLP in marker assisted breeding in the Eurepean Union DGXII Biotechnology FW IV Research Programme Molecular Tools for Biodiversity. EU-Compendium, pp 1-4.

Quarrie SA, Stojanovic J and Pekic S (1999) Improving drought resistance in small-grained cereals: a case study, progress and prospects. Plant Growth Regul 29:1-21.

Ribaut JM, Jiang C, Gonzalez-de-Leon D, Edmeades GO and Hoisington DA (1997) Identification of quantitative trait loci under drought conditions in tropical maize. 2. Yield components and marker-assited selection strategies. Theor Appl Genet 94:887-896.

Smirnoff N (1993) Tansley Review N. 52. The role of active oxygen in the response of Plams to water deficit and desiccation. New Phytol 125:27-58.

Sweeney PM and Danneberger TK (1994) Random Amplified Polymorphic DNA in Perennial Ryegrass: A comparison of bulk samples vs. individuals. HortScience 29:624-626.

Tabaeizadeh Z (1998) Drought-induced responses in plant cells. Int Rev Cytol 182:193-242.

Tanaka K, Masuda R, Sugimoto T, Omasa K and Sakaki T (1990) Water deficiency-induced changes in the contents of defensive substances against active oxygen in spinach leaves. Agric Biol Chem 54:2629-2634.

Teulat B, Rekika D, Nachit M and Monneveux P (1997a) Comparative osmotic adjustments in barley and tetraploid wheats. Plant Breeding 116:519-523.

Teulat B, Monneveux P, Wery J, Borries C, Souyris I, Charrier A and This D (1997b) Relationships between relative water content and growth parameters in barley: a QTL study. New Phytol 137:99-107.

Vos P, Hogers R, Bleeker M, Reijans M, Vande Lee T, Hornes M, Fritjers A, Pot J, Peleman J, Kuiper M and Zabeau M (1995) A new concept for DNA fingerprinting. Nucl Acids Res 23:4407-4414.

Zabeau M and Vos P (1993) Selective restriction fragment amplification: a general method for DNA fingerprinting. European Patent Application 92402629.7 (Publ. N. 0534858 A1).

Associate Editor: Marcio de Castro Silva Filho 